Bozhin Traykov

\section{Crisis, Neoliberalization and the Search for New Historic Bloc}

\section{Bionote}

Bozhin Traykov is a PhD Candidate in Sociology at the University of Alberta, Canada. His main research interest is the interrelation between forms of neoliberalism and forms of nationalism in post-socialist Bulgaria. He is also part of the editorial board of $d V E R S I A$, a magazine for critical left analysis in Bulgaria.

In order to get a better understanding of the crisis of neoliberalism post-2007/2008, I use the theoretical work of Giovanni Arrighi, ${ }^{1}$ as well as Neil Brenner, Jamie Peck and Nik Theodore's concept of neoliberalization. ${ }^{2}$ While acknowledging the different contexts and time periods in which they have developed and the development of current European populism at an earlier stage in

1 Giovanni Arrighi, The Long Twentieth Century: Money, Power and The Origin of Our Times (London and New York: Verso, 1994); Giovanni Arrighi, "Hegemony Unravelling - 1," New Left Review, No. 32 (April, 2005), 23-80; Giovanni Arrighi, "Hegemony Unravelling - 2," New Left Review, No. 33 (June 2005), 83-114.

2 Neil Brenner, Jamie Peck and Nik Theodore, "After Neoliberalization?," Globalizations, Vol. 7, No. 3 (September 2010), 327-45; Neil Brenner, Jamie Peck, and Nik Theodore, "Variegated Neoliberalization: Geographies, Modalities, Pathways," Global Networks, Vol. 10, No. 2 (April 2010), 182222. comparison to the one in North America, I argue that the rise of populism both in the USA and in the EU should be analyzed in the context of the unsuccessful attempts to manage the crisis of global capitalism, characterized by continuation of neoliberal austerity policies. ${ }^{3}$ The current resistance to neoliberalism comes not only from the left, but also from the right, where the voices of what Stuart Hall defines as authoritarian populism become stronger. ${ }^{4}$

\section{Cycles of Accumulation of Global Capitalism}

Giovanni Arrighi coins the term systemic cycles of accumulation (SCA). Arrighi draws on historian Fernand Braudel for whom the developed stages of the capitalist economy are marked by a switch from trade in commodities to trade in money. ${ }^{5}$ Arrighi traces a historical pattern across 600 years of capitalist development. Each cycle is characterized by an increase in scope and intensity of accumulation and shorter duration and consists of phases. In the first phase a period of material expansion is followed by a period of market stagnation. This stagnation signals the second phase characterized by a transition from accumulation of material capital to accumulation of financial capital. Arrighi explains this recurrent pattern according to the circulation of money and commodities in the following way:

The central aspect of this pattern is the alteration of epochs of material expansion... with phases of financial expansion... In the phases of material

3 Brenner, Peck and Theodore, "After Neoliberalization?.”

4 Stuart Hall, "Popular-Democratic vs Authoritarian Populism. Two Ways of Taking Democracy Seriously," in Marxism and Democracy, ed. by Alan Hunt (London: Lawrence and Wishart, 1980), 157-85.

5 Arrighi, The Long Twentieth Century, 109. 
expansion, money capital (M) sets in motion an increasing mass of commodities (C), including commoditized power and gifts of nature; and in phases of financial expansion, an expanded mass of money capital (M') sets itself free from its commodity form, and accumulation proceeds through financial deals... Taken together the two epochs constitute ... systemic cycle of accumulation. ${ }^{6}$

As William Robinson points out, there are two important aspects of Arrighi's world system analysis. ${ }^{7}$ First, the fundamental importance of finance - financial capital for Arrighi is not only a twentieth century stage of world capitalism but a recurring cyclical process, dating back at least to the Italian city states. Second, Arrighi's analysis emphasizes the importance of class reconfiguration among the elite. The initial hegemonic stage, characterized by increased material production and the rule of the producing class gives way to the stage of financial accumulation and the rise of the financial class; the crisis occurs with the rise of the financial class, because it produces nothing but debt. Debt production is concentrated in various supranational institutions such as IMF, World Bank, ECB, etc.

Brenner, Peck and Theodores' thesis of the current state of global capitalism defines neoliberalization as a path-dependent regulatory system aiming at accelerating marketization and commodification in all realms of social life. ${ }^{8}$ Neoliberalization processes have heterogeneous forms, depending on regional context, yet neoliberalization has a consistent operational logic. The authors propose to analyse neoliberaization as a

6 Arrighi, "Hegemony Unravelling - 2," 85.

7 William Robinson "Giovanni Arrighi: Systemic Cycles of Accumulation, Hegemonic Transitions, and the Rise of China," New Political Economy, Vol. 16, No. 2 (Nov 2011), 1-14.

8 Brenner, Peck and Theodore, "After Neoliberalization?.” syndrome of processes and activities rather than as a unified phenomenon. ${ }^{9}$ While after the 2008-2009 global financial crisis neoliberalism has been weakened as an ideological project, its specific regulatory policies are still quite strong. Brenner et al. emphasize that each crisis generates a new set of neoliberal regulatory policies. Therefore, neoliberalizarion is an on-going process, even if the ideology of neoliberalism is morally bankrupt.

The post-2008 stage of late capitalism brings about the emergence of various forms of populism on the right and on the left. Antonio Gramsci's ${ }^{10}$ concept of historic bloc is showing the possibility to think of formation of unlikely alliances with contradictory ideologies. It allows us to think of class as a process, instead of social group. Groups of people with different interests unite around a particular cause that might not be manifested as a class issue. Historic blocs are not necessarily based on class projects, but they are, to use Althusser's term, overdetermined by class position. And such blocs are not always stable, but for Gramsci the contradictions among the various forces can be overcome by articulating a language of the movement. So, at the core of the concept is that historic blocs require leadership that can articulate what Gramsci calls new kinds of common sense, one that is derived from the experience of the subaltern classes and the knowledge of intellectuals, in a dialogical process. ${ }^{11}$

9 Ibid., 330

10 Antonio Gramsci, Selections from the Prison Notebooks of Antonio Gramsci, ed. by Quintin Hoare and Geoffrey NoelSmith (New York: International Publishers, 1971).

11 Kate Crehan, Gramsci's Common Sense: Inequality and Its Narratives (Durham, NC: Duke University Press, 2016), xii. 


\section{War of Position and the Importance of Language}

The problem of intellectual leadership is also a problem of language - leadership requires addressing those that are powerless with a language that speaks to them. Finding a language that speaks to the subaltern classes is key to the ongoing war of position - the element of class struggle to gain influence in society, especially in times of crisis. The language of the left - the legacy of the epos of oppressed and oppressive classes that Stuart Hall ${ }^{12}$ thought was necessary to return is now taken from the opposite side. Yet, we can argue that the Occupy movement brought back this epos. ${ }^{13}$ Occupy put responsibility in the system of capitalism: it is broken because of its own deeds, not some external other. While on the opposite front the Tea Party found enemies of the system to explain free loaders, immigrants, etc. Therefore, I argue that while the Tea Party masked class conflict, Occupy's language indirectly brought class as a process to the front. The slogan "We are the $99 \%$ " is inclusive of all those that suffer from the various forms of inequality of capitalism.

What Gramsci calls organic intellectuals are people in position of intellectual leadership that are organically linked to their social class - they come from their class and know its culture, that is why they should be speaking the language that is understandable, a coherent language that speaks to the oppressed. Bernie Sanders, with his blue-color working class roots, spoke such a language that was easy to understand for those for whom the free market narrative was not common sense. Sanders' project of democratic socialism, as he calls it, appealed to millennials from Occupy but also to the old school

left of the 1960 s and 1970 s that took part in the anti-war

12 Hall, "Popular-Democratic vs Authoritarian Populism."

13 Crehan, Gramsci's Common Sense. movement and became radicalized, and the blue color union workers. Those groups recognized him as their candidate. Sanders articulated the language of Occupy and created a political program out of the slogan $99 \%$. The $99 \%$ are in essence everyone that suffers under debt-producing finance capitalism.

After Sanders' defeat Trump's authoritarian populism won. Key to the Tea Party narrative is the antagonism based on makers and takers (with racial connotations) that Trump articulated in his campaign. In the context of the financial crisis the Tea Party mobilized a populist project based on anger for the poor, coming out of the paranoia of the road to serfdom, one of its paranoid elements was the belief that Obama is a socialist aiming to destroy the American way of life. ${ }^{14}$

Trump used key elements of Tea Party antagonistic language garnished with outright racism and forms of othering based on the us vs them rhetoric. Trump brought the toxic element in the language of antagonism, antagonism that mobilizes moral panics with a plea for traditionalism, vaguely defined as the American way, thus the disdain for liberal political correctness that privileges groups, which in the eyes of the right are aberrant. Trump's dismissal of political correctness, also appealed to the Christian fundamentalists cry for distortion of traditional ways of life, with their claims that schools are breeding ground for aberrant behaviour, aiming to destroy traditional values.

Stuart Hall writes that popular morality is the most practical ideological tool to reach to discontented classes because its language is understandable and maps out the world of problematic social realities and contradictions. ${ }^{15}$ The same mechanism operates

\footnotetext{
14 Ibid., 122.

15 Hall, "Popular-Democratic vs Authoritarian Populism," 143.
} 
with conspiracy theories, which Fredric Jameson calls cognitive mapping of the poor: an attempt to grasp the totality of social relations, within their contradictions. ${ }^{16}$ It is an easy explanation of the world, where an evil elite plans to control the rest of us. Alex Jones is a conspiracy theorist who has millions of followers and is known to be close to Trump. He managed to mobilize the Trump electorate through paranoia, moral panics and a plea for traditionalism. In the context of Thatcherism, Hall has listed those as the characteristics of the discourse of authoritarian populism. In Jones' Manichean discourse the world is ruled by a global elite (globalists) whose New World Order is a program for global totalitarian rule. ${ }^{17}$ Therefore, all elements of the crisis - financial, social, economic, ecological, refugee, are methods of the globalists to achieve their goal. For Jones political correctness is the tool to instil guilt in the white male American of his tradition and culture; this is the overlap with the alt-right, evangelicals, and tea partiers. In his plea for traditionalism Jones presents Trump as the saviour form the globalists that will restore the traditional American way of life.

\section{Bulgarian Neoliberalization and War of Position}

In the Bulgarian context neoliberalization had to restructure the socialist state model. The question of the dominant discourse in Bulgaria is related to the political-economic realities in the country. We should trace two patterns of economic dependence: the first stage of accumulation by dispossession by plundering

16 Fredric Jameson, "Cognitive Mapping," in Marxism and the Interpretation of Culture, ed. by Cary Nelson and Lawrence Grossberg (Urbana-Champaign, Illinois: University of Illinois Press, 1988), 347-58.

17 Bozhin Traykov, "Kraynata igra na Aleks Dzhouns," dVERSIA, No. 7 (March 2017), www.dversia.net/1994/alex-jonessendgame. state assets, where organized crime played a key role, and afterwards a period of harsh shock therapy policies, starting from the late nineties, characterized by rapid privatization. $^{18}$

From the very beginning of the restructuring of the state from planned economy to market economy with neoliberal characteristics, supranational institutions of global capitalism were present as advisers, regulators and at various stages coercive mechanisms that ensure the restructuring process. The decisive role of IMF, World Bank and the EU relate to the state's peripheral position in the system of global capitalism and the resulting socio-economic, political and cultural trends. ${ }^{19}$ As Hilary Appel points out - the further east the country, the harsher the requirements for its inclusion in the system of global capitalism as an EU member. ${ }^{20}$ The consequences of such neoliberal policies in Bulgaria were devastating and brought crisis on all levels, catastrophic demographic picture, unaffordable or dysfunctional healthcare and rapid deterioration of the educational system.

Current Bulgarian liberal apologists of capitalism are not blind to the rapid devastating effects of the restructuring process after 1989. However, instead of a systemic approach they are concerned with the moral aspect of the new market players, focusing on their moral deficits (organized crime groups) that originate from the former

18 Bozhin Traykov, "Parvonachalno natrupvane na kapital: sluchayat Varna," dVERSIA, No. 6 (November 2016), www. dversia.net/1846/kapital_varna.

19 Immanuel Wallerstein, The Modern World-System in the Longue Durée (Boulder, Colorado: Paradigm Publishers, 2004).

20 Hilary Appel, "Western Financial Institutions, Local Actors, and the Privatization Paradigm," Problems of PostCommunism, Vol. 51, No. 5 (2004), 3-10. 
Communist Party elite, i.e., the nomneklatura and State Security (Darzhavna sigurnost - DS) - the repressive apparatus modeled under the KGB. Today, 28 years after the end of the Eastern bloc, communism continues to be the main explanatory mechanism for the "errors" of market economy. Liberals view the capitalist system as infallible a priori, that is why they search for outside causes of the indelible effects of the capitalist system inequality, corruption and violence. For liberals, such effects are due to Russia's sinister role, Communists, cultural deficits, Bulgarian people's mindset, etc.

The dominant anti-communist discourse, interconnected to a back to Europe narrative, imported from EastCentral European intellectual discourses, ${ }^{21}$ serves as an ideological framework that justifies the continuation of neoliberal policies. State and private institutions, such as education, museums, cultural centers, think tanks, public and private media are engaged in producing and reproducing the anti-communist discourse that interprets the past as an explanatory mechanism for the failure of the present.

The current form of anti-communism is related to a specific form of nationalism that aims to revive and rehabilitate compromised historical figures from the monarchist period. Often times the presentation of the whole period of the socialist past as totalitarian, lacking in nuances and layers, is combined with the denial of fascism in Bulgaria. ${ }^{22}$ While analyzing the prevalence of anti-communism we should also take into account the stigmatization of the left and its marginalization. This

21 Barbara Falk J., The Dilemmas of Dissidence in East-Central Europe: Citizen Intellectuals and Philosopher Kings (Budapest and New York: Central European University Press, 2003).

22 Roumen Daskalov, Debating the Past: Modern Bulgarian History. From Stambolov to Zhivkov (Budapest and New York: Central European University Press, 2011), 209. is due to the fact the Bulgarian Socialist Party (BSP), a party that has implemented such neoliberal measures as the flat tax and ten percent corporate tax - the lowest in Europe - has usurped the space of left politics. Therefore, every attempt to introduce social policies in Bulgaria is associated with BSP's corrupt practices.

\section{Liberal Anti-Communist Discourse and Trumpism}

We see how the anti-communist discourse in Bulgaria serves to silence the voices of the past that have a different remembering process. On the one hand, we have the reproduction of selective discourses about the past that present a one-sided picture of the historical period after World War II and on the other, production of present discourses, such as the claims that there was no fascism in Bulgaria. Concentrating on the violence of the past ignores the violence of the present, while submerging previous struggles for the commons in the anti-communist and racist anti-Roma narratives. In a sense, this is the same kind of antagonistic strategy based on moral panics of retrograde social movements, such as the Tea Party movement in the USA, which are exclusive rather than inclusive. What is characteristic of such discourses is the search for an inner enemy with which to explain the failures of the system of capitalism. Boris Buden compares the logic of the current anti-communism of the liberal establishment in East and Southeast Europe to Stalin's search for inner enemies as those responsible for the failure of the Soviet system. ${ }^{23}$ This search for an inside enemy characterizes also Trump's successful campaign for President of the USA. Jones and Trump managed to unite around them all those ridiculed by the educated and economically

23 Neda Genova and Boris Buden, "Za antikomunizma i dvete litsa na komunizma dnes: Intervyu s Boris Buden," dVERSIA, No. 8 (September 2017), ww.dversia.net/2585/ antikomunizma-i-dvete-lica-na-komunizma-boris-buden. 
privileged liberal middle and upper middle class in the US; the deplorables, in the words of Hillary Clinton racist, sexist, xenophobic, homophobic, Islamophobic, etc. Trump's voters are those despised by the liberal class - outside major urban centers and the most negatively affected by the consequences of several decades of neoliberalism. ${ }^{24}$ They feel strangers in their own land ${ }^{25}$ and despite directly suffering from the activities of big business corporations, they are the biggest supporters of deregulation. In the corporation they see jobs, and in regulation - the hand of a corrupt state that stops their wellbeing. The liberal establishment, but also the Tea Party and Trump supporters, have their own list of enemies - whether they are outside forces - Russia, KGB, Communists, or inside forces - the poor, people of color, LGBTQ community, Muslims, etc.

\section{Conclusion}

Trumpism as an authoritarian populist project has been successful because of the unsuccessful left populist project. Sanders' populism was not unsuccessful because of a failure to mobilize the majority and to produce an understandable language for the oppressed, despite all attempts of mass media to ignore him, but because of political manoeuvring within his own party that chose to run with the less popular candidate and brought about the anger of many Democrats and independents, who

24 Andrew Levine, "The Face of the Enemy: Dupes, Deplorables, Opportunists and Democrats," Counterpunch (February 2017), www.counterpunch.org/2017/02/03/the-face-ofthe-enemy-dupes-deplorables-opportunists-and-democrats; Paul Street, "Divide and Rule: Class Hate and the 2016

Election," Counterpunch (January 2017), www.counterpunch. org/2017/01/20/divide-and-rule-class-hate-and-the-2016election.

25 Arlie Hochschild, Strangers in Their Own Land: Anger and Mourning on the American Right (New York: The New Press, 2016). did not vote for Clinton. However, the election of Donald Trump signifies a deep crisis in capitalism and the mobilizing potential of antagonistic language should not be underestimated. A comparative approach between Trump's USA and Bulgarian anti-communist nationalism shows the similarities of an antagonistic language that justifies and channels the anger of the discontented with capitalism by finding various scapegoats. The left have to be engaged in a war of position against the prevalent ideological narratives on the political and cultural front. 